\title{
Design \& Analysis of Steering System for Solar Vehicle
}

\author{
${ }^{1}$ Prof. Rahul R. Patil,${ }^{2}$ Mr. Saurabh Pandurang Mahind, ${ }^{3}$ Mr. Nikhil Ravindra Bhosale
}

1. Assistant Professor,Mechnical Engineering Dept., PVPIT,Sangli-Tasgaon Road,Budhgaon,Sangli,Maharashtra,416304

2. U.G. Students of Mechanical Engineering, PVPIT, Sangli-Tasgaon Road, Budhgaon, Sangli, Maharashtra, 416304

3. U.G.Students of Mechanical Engineering, PVPIT, Sangli-Tasgaon Road, Budhgaon, Sangli, Maharashtra, 416304

\begin{abstract}
This research paper aims for making prototype, steering system for single-seat solar vehicle. Designs are made according to the rules and regulations of the National Solar Vehicle Challenge 2019-20.The decreasing fuel resource in the world makes it a necessary to search for renewable options. This vehicle is a fourwheeler and drive by BLDC hub motor.and also driven by a battery which charged via the solar panels.We are using rack and pinion steering system to turn the vehicle.Rack and pinion steering system selected because of its simplicity,less effort and less cost.Our project requires engineering skills according to the rules of the competition.
\end{abstract}

Keywords-: Analysis, Solar Car, Automobile, Design,rack and pinion,steering system

\section{INTRODUCTION}

The aim of steering arrangement is to turn the front wheels using hand operated steering wheel which is in front of driver through steering column it contains universal joint to allow it to deviate from straight line.

The steering provides stability to vehicle on road.Wear and tear reduces because of steering system. It prevents road shocks reaching to driver.The steering provides self rightening effect after taking a turn.

We are using rack and pinion steering system for our solar vehicle.Because it is simple and most common in cars,small trucks,suvs.A rack and pinion gearbox is enclosed in metal tube.A rod,called tie rod connects to each end of rack.The pinion gear is attached to steering shaft.When you turn steering wheel,gear spins,moving the rackThe tie rod at each end of rack connects to steering arm on spindle.

The steering ratio is the ratio of how you can turn the steering wheel to how far the wheels turn.Generally lighter cars have lower steering ratios than larger cars and trucks. The lower ratio gives steering a quicker response.Smaller cars are light that with lower ratio effort required to steering wheel is not excessive.

\section{METHODOLOGY}

\section{A. Material Selection}

We referring different literatures [1][2] and taken material as Mild Steel (Grade 2)(SAE1018).It has generally good mechanical properties.The mechanical properties of mild steel are given below in table 1 .

TABLE 1 MECHANICAL PROPORTIES OF M.S. SAE1018

\begin{tabular}{|c|c|}
\hline Property & Value \\
\hline Density & $7850 \mathrm{~kg} / \mathrm{m}^{3}$ \\
\hline Melting Point & $1370^{\circ} \mathrm{C}$ \\
\hline Yield Strenth & $240 \mathrm{Mpa}$ \\
\hline Tensile Strength & $370 \mathrm{Mpa}$ \\
\hline Modulus of Elasticity & $205 \mathrm{Gpa}$ \\
\hline Poisson,s Ratio & 0.33 \\
\hline Brinell Hardness & $126 \mathrm{BHN}$ \\
\hline
\end{tabular}

B. Mathematical Calculation-

TABLE 2 ACKERMAN GEOMETRY WITH VALUES

\begin{tabular}{|c|c|}
\hline Geometry & Ackerman Geometry \\
\hline Steering type & Rack and Pinion \\
\hline Wheelbase & $1700 \mathrm{~mm}$ \\
\hline Track width & $1200 \mathrm{~mm}$ \\
\hline Inner wheel angle & $30^{0}$ \\
\hline Outer wheel angle & $22.36^{0}$ \\
\hline Ackerman angle & $32.90^{0}$ \\
\hline Inner turning radius & $3.35 \mathrm{~m}$ \\
\hline Outer turning radius & $4.0 \mathrm{~m}$ \\
\hline Steering ratio & 7.2 \\
\hline
\end{tabular}

We made calculations considering ackerman's mechanism.

So We will explain all mathematical calculation by showing ackerman diagram below [1]. Table 2 shows important parameters required to design steering system. 


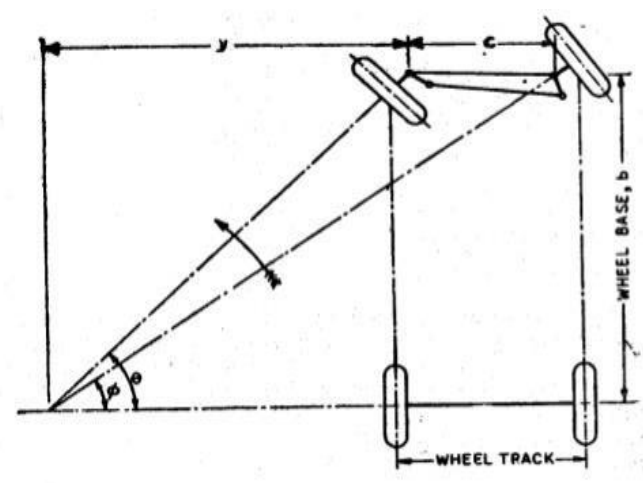

Figure 1: Ackerman Mechanism

According to rules of competition wheelbase, trackwidth and Kingpin distance selected.

Wheelbase $(\mathrm{b})=1700 \mathrm{~mm}$

Trackwidth (a) $=1200 \mathrm{~mm}$

Distance between kingpin $(\mathrm{c})=1100 \mathrm{~mm}$

Inner wheel angle $(\Theta)=30^{\circ}$

Outer Wheel angle $(\omega)=22.36^{\circ}$

Ackerman angle $(\alpha)=\tan ^{-1}(\mathrm{c} / \mathrm{b})=32.90^{\circ}$

\section{Turing Radius}

Inner turning radius

$\mathrm{R}_{\mathrm{in}}=\mathrm{b} / \sin (\Theta)-(\mathrm{a}-\mathrm{c} / 2)$

Outer turing radius

$=3.35 \mathrm{~m}$

Rout $=\mathrm{b} / \sin (\omega)+(\mathrm{a}-\mathrm{c} / 2)$

$$
=4.01
$$

\section{Steering Ratio}

Maximum turn $=250 \quad$......(Assume)

Steering wheel movement $=1800$

Therefore,

Steering Ratio(S.R.) $=180 / 25=7.2$

\section{Design of Pinion}

1. Material for rack and pinion =Mild Steel ..(I.S. specifications)

2. Minimum No. of teeth for pinion:-

$$
\begin{aligned}
\mathrm{Z}_{\mathrm{pmin}} & =2 / \sin ^{2}(\text { outer wheel angle }) \\
& =17.09=18 . \\
\text { Module } & =2
\end{aligned}
$$

3. For $20^{\circ}$ full Depth involute system (outer wheel angle $=20^{\circ}$ )

4. Addendum $(\mathrm{ha})=1 * \mathrm{~m}=2 \mathrm{~mm}$.

5. Deddendum $\left(\mathrm{h}_{\mathrm{f}}\right)=1.25 *$ module $=2.5 \mathrm{~mm}$.

6. Pitch circle diameter $\left(\mathrm{d}^{!}\right)=$module $* \mathrm{Z}=36 \mathrm{~mm}$.

7. Addendum circle diameter $(\mathrm{da})=\mathrm{M}^{*}(\mathrm{Z}+2)=40 \mathrm{~mm}$.

8. Deddendum circle diameter $\left(d_{\mathrm{f}}\right)=M *(Z-2.5)=31 \mathrm{~mm}$.

9. Clearance $(\mathrm{c})=0.25 * \mathrm{M}=0.5 \mathrm{~mm}$.

10. Whole depth $=2.25 * \mathrm{M}=4.5 \mathrm{~mm}$.

11. Tooth thickness $=1.5708 * \mathrm{M}=3.14 \mathrm{~mm}$.

12. Circuler pitch $=\left(3.14 * d^{\prime}\right) / Z$

$$
=(3.14 * 36) / 18
$$$$
=6.28 \mathrm{~mm} \text {. }
$$

13. Diametral pitch $=\mathrm{Z} / \mathrm{d}^{!}=0.5$

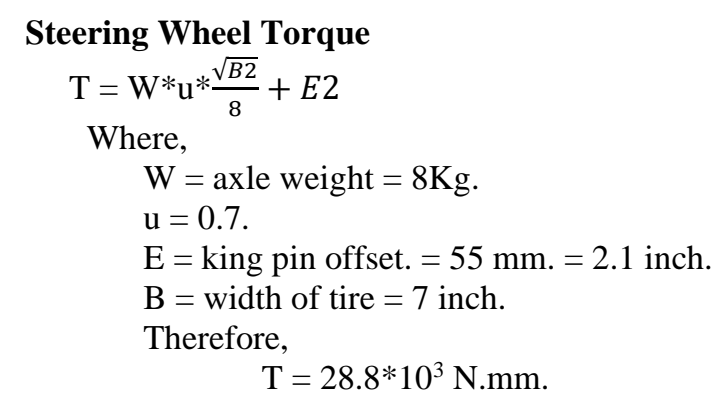

Torque on Pinion

$$
\begin{aligned}
(\mathrm{T}) & =(\mathrm{T} * \mathrm{Zr} / \mathrm{Zp}) / \mathrm{d} p \\
& =12 * 10^{3} \text { N.mm. }
\end{aligned}
$$

\section{Beam Strength Equation}

$\mathrm{S}_{\mathrm{ut}}=1500 \mathrm{Mpa}$.

Bending strength $=\mathrm{S}_{\mathrm{ut}} / 3=500 \mathrm{Mpa}$.

No. of teeth on pinion. $=18$

Pr. Angle $=20^{\circ}$.

Lewis form factor $\left(\mathrm{Y}_{\mathrm{p}}\right)=0.308$

FOS recommended by 1.5 to 2 .

Therefore,

$\mathrm{FOS}=1.5$.

$\mathrm{S}_{\mathrm{b}}=\mathrm{P}_{\text {eff. }} *$ FOS

But,

$\mathrm{P}_{\text {eff. }}=\left(\mathrm{C}_{\mathrm{s}} / \mathrm{C}_{\mathrm{v}}\right) * \mathrm{Pt}$.

$\mathrm{Cs}=1.05$

$\mathrm{C}_{\mathrm{v}}=3 / 3+\mathrm{v}$

$\mathrm{C}_{\mathrm{v}}=0.9836$.

$\mathrm{P}_{\mathrm{t}}=(2 * \max$. Torque $) /($ No. of teeth $*$ Module $)$ $=1600 \mathrm{~N}$.

Hence,

$$
\begin{aligned}
& \text { Beam strength }\left(\mathrm{S}_{\mathrm{b}}\right)=\mathrm{M} * \mathrm{~b}^{*} / 3 * \mathrm{Y}_{\mathrm{p}} \\
& =3080 \mathrm{~N} \text {. }
\end{aligned}
$$

\section{Wear Strength}

$\left(S_{\mathrm{w}}\right)=\mathrm{b} * \mathrm{Q} * \mathrm{~d} \mathrm{p}^{* \mathrm{~K}}$

Where,

$\mathrm{b}=$ Face width of gear $\quad$......(Assume $10 \mathrm{~mm}$.)
$\mathrm{Q}=$ Gear ratio factor

$$
=(2 \mathrm{Zr}) /(\mathrm{Zr}+\mathrm{Zp})=1.47
$$

$\mathrm{K}=$ Material constant (250)

$\mathrm{d}^{\prime} \mathrm{p}=$ pitch circle diameter of pinion. $(36 \mathrm{~mm})$

$$
\begin{aligned}
\mathrm{S}_{\mathrm{w}} & =\mathrm{b}^{*} \mathrm{Q} * \mathrm{~d} \mathrm{p}^{*} \mathrm{~K} \\
& =10^{*} 1.47 * 36^{*} 250 \\
& =132.3 * 10^{3} \mathrm{~N}
\end{aligned}
$$

\section{Steering Effort}

Mass of vehicle $=230+70=300$

Centre of gravity $=250 \mathrm{~mm}$.

Diameter of steering wheel $=14.5$ inch. $=368.5 \mathrm{~mm}$.

Radius of pinion $=20 \mathrm{~mm}$.

Therefore,

Steering effort $=97.69 \mathrm{~N}$.

Torque of pinion $(\mathrm{T})=\left(\mathrm{T}^{*} \mathrm{Zr} / \mathrm{Zp}\right) / \mathrm{d} ! \mathrm{p}$ $=12 * 10^{3}$ N.mm. 


\section{Dimensions Of Rack}

Rack shaft length $=15$ inch $=381 \mathrm{~mm}$.

No. of teeth on rack $=50$.

Steering lock $=30^{\circ}$.

Rack eye to eye length $=14$ inch $=355.6 \mathrm{~mm}$.

Rack center lock $=3.5$ inch $=88.9 \mathrm{~mm}$.

Rack tooth thickness $=3.25 \mathrm{~mm}$

Rack pitch $=6.5 \mathrm{~mm}$.

Addendum and deddendum $=2 \mathrm{~mm}$.

Clearance $=0.5 \mathrm{~mm}$.

Travel lock to lock $=4.48 \mathrm{inch}=113.79 \mathrm{~mm}$

Pinion Radius $=0.78$ inch $=20 \mathrm{~mm}$.

( Note :- As per standard rack size.)

Length of tie rod $=8$ inch $=203.2 \mathrm{~mm}$.

Arm length $=4.3$ inch $=109.22 \mathrm{~mm}$.

Steering shaft length $=750 \mathrm{~mm}$.

Steering shaft diameter $=12 \mathrm{~mm}$. (pinion to column joint)

\section{Steering Wheel}

According to standard dimensions steering wheel diameter ranges from 141/2 to 171/2 inch and grip circumference ranges from 23/4 to 41/4 inches.

Generally from 2009, 141/2 inch wheel diameter is used with grip circumference of 23/4.

Steering wheel travel for one complete revolution $=2 * 3.14 * \mathrm{r}$

$=19.72 \mathrm{~mm}$

\section{C.Cad Modeling}

Cad modeling of steering system is done using Solidworks. Finite element models are developed using Ansys 16.0.A stress analysis can be carried out to determine stress produced in rack and pinion.Figure [2],[3],[4] shows CAD models of rack and pinion before assembly and after assembly.And figure [5] shows final CAD model of steering system.

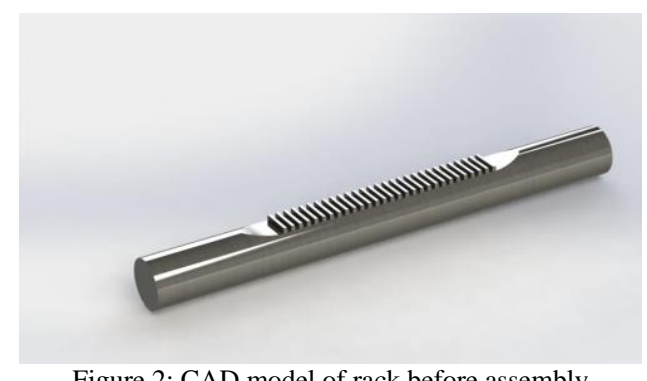

Figure 2: CAD model of rack before assembly

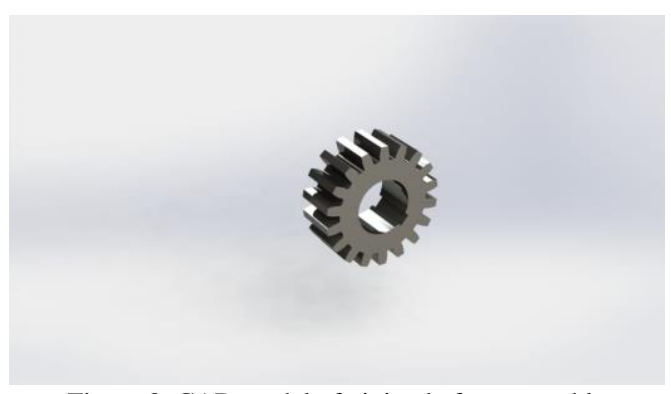

Figure 3: CAD model of pinion before assembly

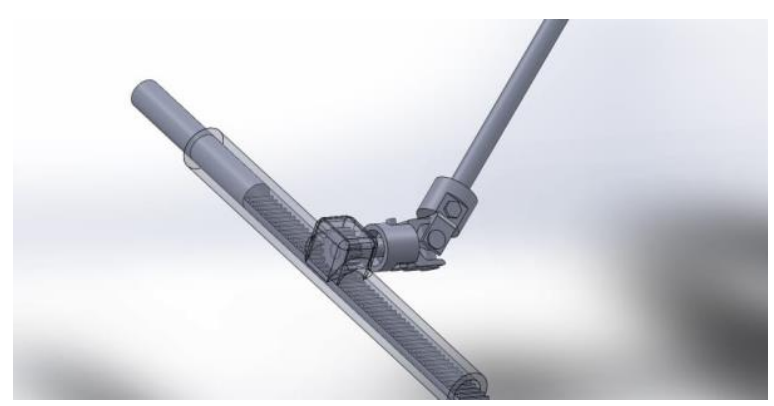

Figure 4: CAD model after assembly of rack and pinion

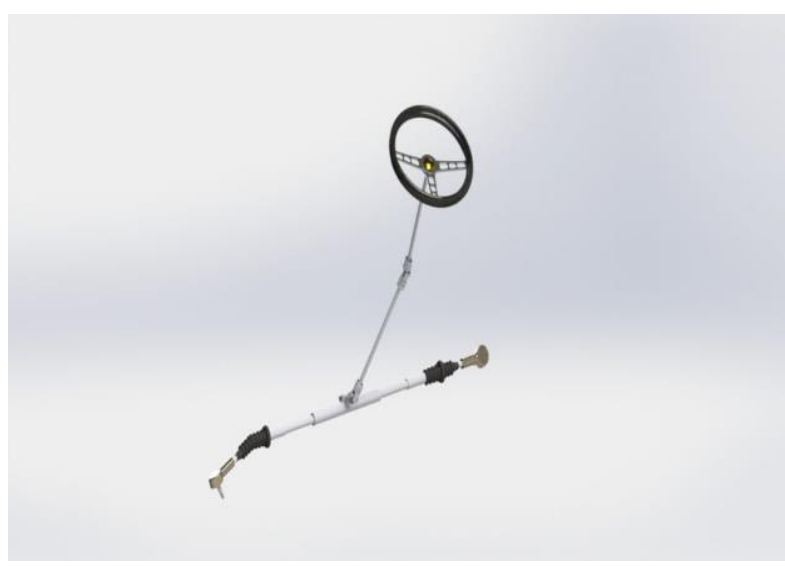

Figure 5: CAD model of final steering system

\section{ANALYSIS OF STEERING SYSTEM}

Solving therotical calculations are tough due to comlex equation so we deside to use software for analysis and validation.Finite Element Analysis(FEA) is generally used.We choose ANSYS APDL Mechanical 16.0 software to do analysis of rack and pinon in steering system

\section{A. Analysis of Rack}

It has been assumed that if maximum stress is applied on rack then it can not break but we apply $1600 \mathrm{~N}$ force because this is effort required to rotate rack as well as pinion.So considering this force we can carried out analysis of rack. As shown in figure [6].Results shown in table

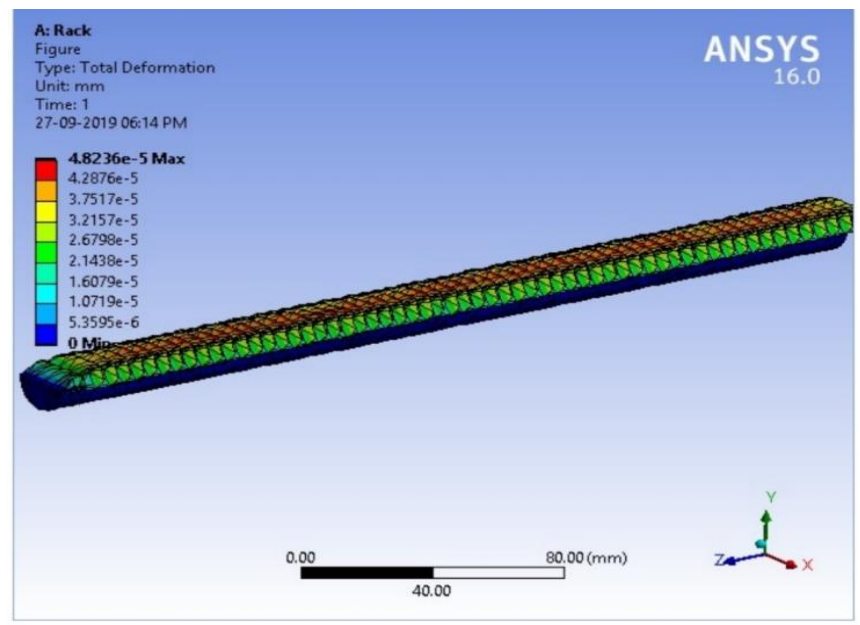

Figure 6:Analysis of rack 
TABLE 3 RESULTS OF ANALYSIS OF RACK

\begin{tabular}{|l|l|}
\hline Force Applied & $1600 \mathrm{~N}$ \\
\hline Max. Stress (Von-Mises) & $2.90 \mathrm{Mpa}$ \\
\hline Max. Deformation & $0.00004 \mathrm{~mm}$ \\
\hline
\end{tabular}

\section{B. Analysis of Pinion}

It has been assumed that we are applying same force of $1600 \mathrm{~N}$ because it has same material as that of rack.Now considering this force analysis of pinion is carried out.As shown in figure [7]. Results shown in table 4.

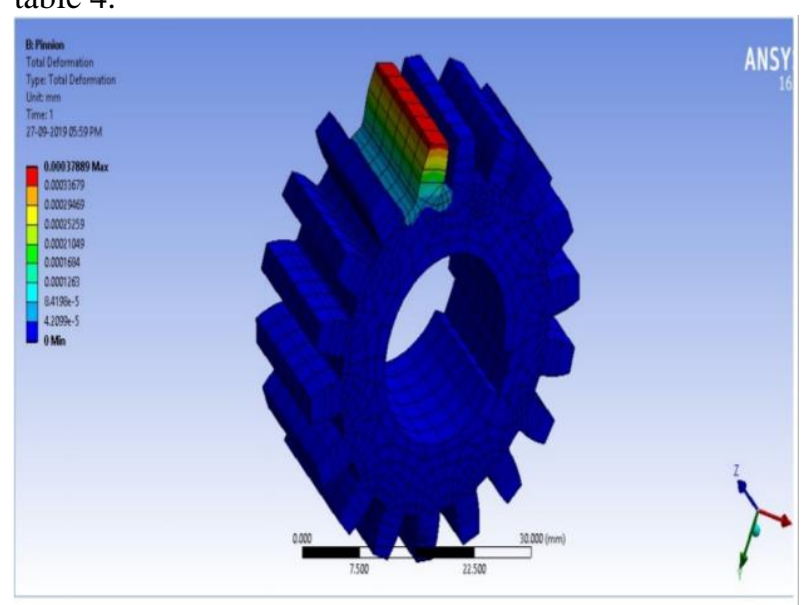

Figure 7: Analysis of Pinion

TABLE 3 RESULTS OF ANALYSIS OF PINION

\begin{tabular}{|l|l|}
\hline Force Applied & $1600 \mathrm{~N}$ \\
\hline Max. Stress (Von-Mises) & $9.830 \mathrm{Mpa}$ \\
\hline Max. Deformation & $0.000037 \mathrm{~mm}$ \\
\hline
\end{tabular}

\section{CONCLUSION}

We compare values therotically and also with ansys software from we can conclude that deformation produced will be negligible and it can sustain at above mentioned stress.So design is safe.The manual rack and pinion steering system not used in heavy weight vehicles due to high axle loads but it is simple in design and easy to manufacture.Therefore it is commonly used in light vehicles.

\section{REFERENCES}

[1] Rules and Regulation of National Solar Vehicle Challenge 2020.

[2] 'Design and simulation of manual rack and pinion steering system' in July 2016 at JSART by Prasant L Agrawal, Sahil Shaileshbhai Patel, Shivanshu Rajeshbhai Parmar

[3] 'Design of steering system for solar car' at BRAC University Dhaka,Bangladesh.

[4] 'Design and fabrical of electric- solar vehicle' in September 2018 at IRJET by Rishabh S Khobragade,Swapnil L Mandawkar,Kalpak A Mahajan,Jay S Takalkhede

[5] 'Design of steering gear system in passenger cars' in January 2018 at IRJET by Rayappa Mahale,Mohit Jaiswar,Gaurav Gupta,Abhishek Kumar 